\title{
ZARZĄDZANIE RELACJAMI B2B W USŁUGACH PRODUKCYJNYCH I BUDOWANIE LOJALNOŚCI RELACYJNEJ
}

\begin{abstract}
Zarządzanie relacjami B2B w działalności przedsiębiorstw świadczących usługi produkcyjne staje się coraz ważniejszym zagadnieniem w dobie globalnych, wzajemnie powiązanych i coraz bardziej konkurencyjnych rynków. Istotnym efektem zarządzania relacjami B2B jest lojalność klientów, którzy podejmują częściej niż nielojalni i z większym zaangażowaniem inicjatywy współpracy, nieodzowne w realizacji usług produkcyjnych. W budowaniu lojalności relacyjnej w usługach produkcyjnych wykorzystano teoretyczny model zaproponowany przez Siemieniako ${ }^{2}$. Cele artykułu to identyfikacja i rozpoznanie mechanizmów powstawania lojalności relacyjnej, a także działań świadczących o lojalności oraz efektów lojalności w procesie zarządzania relacjami B2B w kontekście związków usługowych w działalności produkcyjnej. Zastosowano dwie metody badawcze: wywiad swobodny oraz studium przypadku. Próbę badawczą stanowiły przedsiębiorstwa świadczące usługi produkcyjne, głównie z branż związanych z produkcją różnego typu urządzeń, maszyn i komponentów. Wyniki badań własnych przedstawiono na podstawie modelu zarządzania relacjami w usługach produkcyjnych w kierunku budowania lojalności relacyjnej, składającego się z siedmiu elementów składowych. Wzajemne dopasowanie procesów, kultury organizacyjnej i na poziomie personalnym zostało ukazane jako istotny czynnik rozwoju relacji i budowania lojalności. Sposób działania ze strony usługodawców związany ze zrozumieniem potrzeb klientów, podejmowaniem zobowiązań i dotrzymywaniem obietnic wyznacza poziom rozwoju współpracy z klientami pochodzącymi z państw zachodnich. Warunkuje to zaufanie i podejmowanie zobowiązań ze strony tych klientów. Analiza wyników umożliwiła zidentyfikowanie cech lojalności relacyjnej oraz działań świadczących o lojalności. Wyniki badań ukazały także efekty lojalności oraz elementy systemu zarządzania w organizacji, które wpływają na efektywne zarządzanie relacjami ze wskazaniem na budowanie lojalności relacyjnej.
\end{abstract}

Słowa kluczowe: lojalność relacyjna, marketing relacji, usługi produkcyjne, studium przypadku, zarządzanie obietnicą.

\section{USLUGI PRODUKCYJNE JAKO KONTEKST BADAŃ ORAZ WPROWADZENIE}

Zarządzanie relacjami (relationships) B2B (business-to-business) wchodzi w zakres marketingu i jest zagadnieniem ważnym oraz często poruszanym zarówno w teorii, jak i w praktyce. Kontekstem badań zarządzania relacjami B2B ze wskazaniem na budowanie lojalności, przedstawionych w niniejszym artykule, jest działalność w dziedzinie usług produkcyjnych, świadczonych przez przedsiębiorstwa zlokalizowane w Polsce. Odbior-

\footnotetext{
${ }^{1}$ Dariusz Siemieniako, dr, Politechnika Białostocka, Wydział Zarządzania, ul. o. S. Tarasiuka 2, 16-001 Kleosin, e-mail: d.siemieniako@pb.edu.pl

${ }^{2}$ D. Siemieniako, Model zarzadzania lojalnościq relacyjna oparta na zobowiazaniu w zwiazkach ustugowych, „Marketing i Rynek” 2012/5, s. 8-14.
} 
cami tych usług są najczęściej znane koncerny pochodzące z krajów najbardziej rozwiniętych gospodarczo, oferujące na rynkach globalnych produkty $\mathrm{z}$ własnymi markami.

$\mathrm{Z}$ punktu widzenia zarządzania relacjami B2B w usługach produkcyjnych w Polsce można wyróżnić dwie grupy przedsiębiorstw. Do pierwszej z nich można zakwalifikować przedsiębiorstwa, których podstawową działalnością jest świadczenie usług produkcyjnych głównie dla zachodnich koncernów, tj. pochodzących przede wszystkim z państw Europy Zachodniej oraz z USA. Pierwsza grupa przedsiębiorstw w ogóle albo w niewielkim stopniu wytwarza produkty z własną marką i przedsiębiorstwa to są popularnie nazywane „montowniami”. W związku z taką strukturą działalności produkcyjnej borykają się one z różnymi problemami, takimi jak uzyskiwanie stosunkowo niskiej marży, uzależnienie od jednego klienta, niepewność co do długoterminowych zamówień, niska innowacyjność oraz zwiększone bariery wprowadzenia na rynek produktów z marką własną. Do drugiej grupy należą przedsiębiorstwa, które mają bardziej rozwinięte kompetencje niż pierwsza grupa (np. projektowanie produktów, własne kanały dystrybucji) pozwalające na oferowanie szerszego wachlarza usług produkcyjnych oraz projektowanie, wytwarzanie i dystrybuowanie produktów z własną marką.

Analizowane relacje B2B w usługach produkcyjnych charakteryzują się długoterminowością oraz wymogiem intensywnych kontaktów z klientami, a także często wysokim poziomem zaangażowanego kapitału po jednej lub obu stronach relacji, wysokim poziomem złożoności procesów realizacji usług oraz pewnym poziomem ryzyka niepowodzeń w realizacji usług. Elementem złożoności tych związków usługowych jest także konieczność zaangażowania innych podmiotów w procesy realizacyjne usługodawcy.

$\mathrm{W}$ obu przedstawionych grupach przedsiębiorstw świadczących usługi produkcyjne istotną kwestią jest budowanie lojalności klientów. Jest to główny cel zarządzania relacjami B2B ${ }^{3}$.

Celami artykułu są identyfikacja i zrozumienie mechanizmów powstawania lojalności relacyjnej, a także działań świadczących o lojalności oraz efektów lojalności w procesie zarządzania relacjami B2B, w kontekście związków usługowych w działalności produkcyjnej, na podstawie modelu zaproponowanego przez Siemieniako ${ }^{4}$. Jako metody badawcze zastosowano: wywiad swobodny oraz studium przypadku. Jednostkami badań były przedsiębiorstwa świadczące usługi produkcyjne, głównie z branż związanych z produkcją różnego typu urządzeń, maszyn i komponentów.

\section{BUDOWANIE LOJALNOŚCI RELACYJNEJ B2B JAKO EFEKT MARKETINGU RELACJI W ŚWIETLE LITERATURY}

Marketing relacji (lub relacyjny) koncentruje się na strategii i taktyce budowania wzajemnych korzystnych relacji z klientami, a następnie na rozwijaniu i utrzymywaniu tych relacji w długiej perspektywie. W licznych badaniach ${ }^{5}$ dotyczących marketingu relacyjnego wskazuje się, że podstawowymi zmiennymi tej koncepcji są zaufanie i zaangażowanie

\footnotetext{
${ }^{3}$ I. Geiger, M. Kleinaltenkamp, Instruments of Business Relationship Management, [w:] Business Relationship Management and Marketing, red. M. Kleinaltenkamp, I. Geiger, W. Plinke, Springer, Berlin 2015, s. 196.

${ }^{4}$ D. Siemieniako, Model...

${ }^{5}$ R.M. Morgan, S.D. Hunt, The commitment-trust theory of relationship marketing, ,Journal of Marketing” 58/3 (1994), s. 20-38; D.I. Gilliland, D.C. Bello, Two sides to attitudinal commitment: The effect of calculative and loyalty commitment on enforcement mechanisms in distribution channels, „Journal of the Academy of Marketing Science" 30/1 (2002), s. 24-43.
} 
(lub zobowiązanie) stron relacji, które oprócz satysfakcji są też traktowane jako poprzedniki lojalności klientów.

W złożonych związkach usługowych, zwłaszcza z intensywnym kontaktem, rozumienie lojalności jako koncepcji statycznej i z jednokierunkowym przepływem lojalnych zachowań i postaw wyłącznie ze strony klienta wobec usługodawcy nie sprawdza się w praktyce $^{6}$. Realizacja długoterminowych i złożonych usług produkcyjnych z koniecznością dużego zaangażowania stron relacji wymaga wzajemnej lojalności. Zgodnie z teorią związków Fournier ${ }^{7}$ postawy i zachowania lojalności dotyczą obu stron związku, co oznacza, że lojalność charakteryzuje się wzajemnością. Lojalność o charakterze relacyjnym (wzajemnym) powstaje w ramach intensywnych kontaktów, w których dochodzi do interakcji między stronami. W taki sposób jest też rozumiana lojalność z perspektywy klientów na podstawie badań przeprowadzonych przez Siemieniako i innych w pięciu krajach ${ }^{8}$. Na podstawie wyników tych badań pokazano, że poza relacyjnością innymi cechami lojalności są: złożoność (ukierunkowanie na różne obiekty), dynamika (ewolucja lojalności w procesie interakcji), wymóg zaufania (budowa zaufania polega na dotrzymywaniu obietnic), trwałość i wierność sobie nawzajem oraz wymóg wolnej woli obu stron relacji.

Geiger i Kleinaltenkamp podkreślają konieczność ujmowania lojalności w relacjach B2B w ujęciu czasowym, ,ponieważ lojalność jest w swojej naturze związana z czasowością, ustanowienie status quo nie jest wystarczające, aby osiągnąć długoterminowe korzyści klienta. Lojalność powstaje w relacji biznesowej w rozpiętości czasowej i musi być ciągle rozwijana"9. Podobnie Aksoy i inni dostrzegają dynamiczną naturę lojalności ${ }^{10}$.

Według Naumanna i innych ${ }^{11}$, którzy analizują kierunki przyszłych badań lojalności na rynku B2B, powstawanie i rozwój lojalności klienta na rynku B2B odbywa się pod wpływem wielu czynników, są to: czynniki po stronie klienta (zwłaszcza satysfakcja), sytuacja w branży i czynniki konkurencyjne, czynniki po stronie przedsiębiorstwa (na przykład zmiana strategii) oraz czynniki makroekonomiczne.

Lojalność jako zachowanie oraz postawa jest więc nieodzownym rezultatem zdrowej i skutecznej relacji partnerstwa w realizacji usług produkcyjnych i jak wskazuje się w większości badań, powstawanie lojalności relacyjnej między partnerami jest efektem wykorzystania marketingu relacji ${ }^{12}$.

Badania dotyczące relacji w sferze B2B pokazują, że lojalni klienci częściej i z większym zaangażowaniem podejmują inicjatywy współpracy niż nielojalni ${ }^{13}$, które są nieodzowne w realizacji usług produkcyjnych. Na podstawie wielu badań stwierdzono, że siła

${ }^{6}$ D. Siemieniako, Lojalność klientów - historia czy rzeczywistość marketingu?, „Marketing i Rynek” 2010/5, s. 19.

${ }^{7}$ S. Fournier, Consumers and Their Brands: Developing Relationship Theory in Consumer Research, „Journal of Consumer Research" 24/4 (1998), s. 343-373.

${ }^{8}$ D. Siemieniako, S. Rundle-Thiele, W. Urban, Understanding loyalty from a customer's perspective, ,Journal of Customer Behaviour" 9/3 (2010), s. 283-298.

${ }^{9}$ I. Geiger, M. Kleinaltenkamp, op. cit., s. 196.

${ }^{10} \mathrm{~L}$. Aksoy, How do you measure what you can't define? The current state of loyalty measurement and management, ,Journal of Service Management” 24/4 (2013), s. 356-381.

${ }^{11}$ E. Naumann, P. Williams, M.S. Khan, Customer satisfaction and loyalty in B2B services: directions for future research, „The Marketing Review” 9/4 (2009), s. 319-333.

${ }^{12}$ A. Lindgreen, F. Wynstra, Value in business markets: what do we know?, „Industrial Marketing Management” 34/7 (2005), s. 732-748.

${ }^{13}$ I. Gil-Saura, M. Frasquet-Deltoro, A. Cervera-Taulet, The value of B2B relationships, „Industrial Management \& Data Systems" 109/5 (2009), s. 593-609. 
relacji przedsiębiorstwa z klientem, o której świadczy między innymi lojalność, jest istotnym wskaźnikiem wyników firmy ${ }^{14}$. Praktycznie dla każdej firmy podejmowanie wysiłku w tworzeniu, utrzymywaniu i wzmacnianiu lojalności klientów jest imperatywem długoterminowego sukcesu przedsiębiorstwa. Według Woodrufa ${ }^{15}$ lojalność klientów może być traktowana jako źródło przewagi konkurencyjnej, mając istotny wpływ na wyniki przedsiębiorstwa. Podejmowanie kooperacji z relacją opartą na lojalności zasadniczo prowadzi do uzyskiwania wzajemnych korzyści przez obie strony oraz przyczynia się do podnoszenia konkurencyjności i redukcji kosztów transakcyjnych. Utrzymywanie i rozwijanie długoterminowych relacji B2B jest wzajemnie korzystne i może się przyczyniać do osiągania między innymi następujących efektów: zwiększanie efektywności, dzielenie ryzyka między stronami relacji, tworzenie wartości dodanej ${ }^{16}$.

\section{PODSTAWOWE ZAŁOŻENIA MODELU ZARZĄDZANIA LOJALNOŚCIĄ RELACYJNĄ ZAPROPONOWANEGO PRZEZ SIEMIENIAKO ${ }^{17}$}

W zarządzaniu marketingiem relacji w złożonych związkach usługowych B2B z intensywnym kontaktem Siemieniako ${ }^{18}$ zaproponował model zarządzania lojalnością relacyjną, wykorzystujący koncepcję zarządzania obietnicą ${ }^{19}$. Model ten ukazuje powstawanie i rozwijanie lojalności relacyjnej zarówno po stronie klienta, jak i usługodawcy. Celem modelu jest także przedstawienie zależności pomiędzy działaniami usługodawcy, związanymi z zarządzaniem obietnicą, a powstawaniem zobowiązania ze strony klienta towarzyszącemu jego lojalności wobec usługodawcy.

Koncepcja zarządzania obietnicą w procesach usługowych, która może być traktowana jako szczególny sposób zarządzania marketingiem relacyjnym, wydaje się szczególnie przydatna w budowie lojalności relacyjnej w usługach produkcyjnych. Ze względów praktycznych w zarządzaniu obietnicą można wyodrębnić trzy obszary: składanie obietnic, dotrzymywanie obietnic i umożliwianie spełniania obietnic. Istotą tej koncepcji są dotrzymywanie obietnic dla klienta oraz maksymalizacja wartości u klienta, innymi słowy maksymalizacja różnych korzyści w symultanicznych procesach usługowych wytwarzania i konsumpcji. W procesach usługowych przedsiębiorstwo składa klientom propozycję wartości, jak również współtworzy wartość klienta za pomocą interakcji. Można mówić o podejściu do zarządzania interakcjami w usługach na bazie koncepcji obietnicy i wartości w użyciu ${ }^{20}$. Marketing interaktywny jest adekwatny w usługach B2B z intensywnym kontaktem. Koncepcja zarządzania obietnicą jest szczególnie ważna w bilateralnych mo-

\footnotetext{
${ }^{14}$ R.T. Rust, K.N. Lemon, V.A. Zeithaml, Return on marketing: using customer equity to focus marketing strategy, ,Journal of Marketing” 68/1 (2004), s. 109-127.

${ }^{15}$ R.B. Woodruff, Customer value: The next source for competitive advantage, ,Journal of the Academy of Marketing Science" 25/2 (1997), s. 139-153.

${ }^{16}$ J. Barry, T.S. Terry, Empirical study of relationship value in industrial services, „Journal of Business \& Industrial Marketing" 23/4 (2008), s. 228-241.

${ }^{17}$ D. Siemieniako, Model...

${ }^{18}$ Ibidem.

${ }^{19}$ C. Grönroos, Marketing as promise management: regaining customer management for marketing, ,Journal of Business \& Industrial Marketing” 24/5-6 (2009), s. 351-359.

${ }^{20}$ C. Grönroos, Search of New Logic for Marketing: Foundations of Contemporary Theory, John Wiley \& Sons, London 2007, s. 203
} 
delach współpracy ${ }^{21}$. Koncepcja ta jest osadzona w szerszym paradygmacie logiki usługowej dominacji (SDL, service dominant logic), zaproponowanej po raz pierwszy przez Vargo i Luscha ${ }^{22}$, a w literaturze krajowej omawianej przez Siemieniako ${ }^{23}$ na przykładzie usług finansowych.

Wykorzystanie koncepcji zarządzania obietnicą powinno prowadzić do zatrzymania klientów oraz do wzajemnej lojalności między stronami związków usługowych. Potwierdzają to wyniki badań Hetesi ${ }^{4}$ dotyczących więzią międzyorganizacyjnych dostawców i nabywców. Według nich zaufanie, zobowiązanie i wiarygodność są istotne we wzajemnej lojalności obu stron związku. Spośród wielu badanych przez Hetesi przejawów lojalności po stronie dostawców i nabywców najwyższe lub prawie najwyższe noty w sześciostopniowej skali Likerta uzyskały stwierdzenia dotyczące przejawów lojalności odnoszących się do dotrzymywania obietnic.

Początkowymi działaniami w zarządzaniu lojalnością relacyjną, stanowiącymi elementy składowe modelu zaproponowanego przez Siemieniako ${ }^{25}$, są: wzajemne dopasowanie usługodawcy i klienta oraz empatia okazana klientowi i składanie obietnic przez usługodawcę. Na rynku B2B w złożonych usługach z intensywnym kontaktem, z długim cyklem usługowym ważne jest, aby przekazana potencjalnemu klientowi obietnica, dotycząca propozycji wartości, była z jednej strony atrakcyjna, z drugiej zaś nie powinna być przesadzona, ponieważ już w pierwszym obszarze zarządzania obietnicą zostanie uniemożliwione jej dotrzymanie. Siemieniako ${ }^{26}$ przedstawił także zagadnienie roli i pomiaru empatii personalnej i organizacyjnej w budowaniu lojalności relacyjnej.

Dalej model wskazuje na konieczność podejmowania działań ze strony usługodawcy wpisujących się w koncepcję zarządzania obietnicą, takich jak: zobowiązanie ze strony usługodawcy wobec klienta oraz współtworzenie wartości przez usługodawcę i dotrzymywanie obietnic. Istotność wpływu dotrzymywania obietnic na wzajemność lojalności w działalności usługowej z intensywnym kontaktem sprawia, że można mówić o zarządzaniu lojalnością opartą na zobowiązaniu. Należy zauważyć, że lojalność i zobowiązanie mogą występować według Siemieniako ${ }^{27}$ niezależnie od siebie oraz jednocześnie - zarówno u klientów, jak i usługodawców. Autor ten wskazał na cztery poziomy zobowiązania w złożonych związkach usługowych ${ }^{28}$ :

- zobowiązanie wobec uznawanych normom i przekonań;

- zobowiązanie jako postawa wdzięczności wobec drugiej strony w relacji usługowej;

\footnotetext{
${ }^{21}$ T.A. Taylor, Supply chain coordination under channel rebates with sales effort effects, „Management Science” 48/8 (2002), s. 992-1007.

${ }^{22}$ S.L. Vargo, R.F. Lusch, Evolving to a New Logic for Marketing, ,Journal of Marketing” 68/1 (2004), s. 1-17.

${ }^{23}$ D. Siemieniako, Logika ustugowej dominacji w marketingu - podstawowe pojęcia i konsekwencje w zarzadzaniu, „Marketing i Rynek” 2008/11, s. 11-16; idem, Zarzadzanie obietnica w logice ustugowej dominacji w dobie kryzysu zaufania (na przyktadzie ustug finansowych), „Handel Wewnętrzny” maj 2009, s. 73-82.

${ }^{24}$ E. Hetesi, The Effects of Recession on B2B Loyalty, ,Journal of Marketing Development and Competitiveness" 8/2 (2014), s. 26-37.

${ }^{25}$ D. Siemieniako, Model...

${ }^{26}$ D. Siemieniako, Rola empatii w budowaniu lojalności relacyjnej klientów, „Zeszyty Naukowe Uniwersytetu Szczecińskiego. Problemy Zarządzania, Finansów i Marketingu” 2010/15, s. 19-27.

${ }^{27}$ D. Siemieniako, Lojalność relacyjna a zobowiazanie w ztożonych zwiazkach ustugowych, „Marketing i Rynek" 2011/8, s. 10-15.

${ }^{28}$ D. Siemieniako, Typy lojalności relacyjnej opartej na zobowiazaniu $w$ złożonych zwiazkach ustugowych, „Handel Wewnętrzny” 2012/1, s. 144-152.
} 
- zobowiązanie jako niewiążąca prawnie deklaracja wobec drugiej strony w relacji usługowej;

- zobowiązanie jako umowa stosunku prawnego z drugą stroną w relacji usługowej.

Siemieniako wyróżnił także cztery typy lojalności relacyjnej, w których występują różne poziomy zobowiązania. Począwszy od zobowiązania na wszystkich poziomach, a skończywszy na zobowiązaniu tylko na poziomie zobowiązania wobec uznawanych norm i przekonań, zostały wyróżnione następujące typy lojalności relacyjnej29:

- $\quad$ lojalność zaangażowana z decyzją rozwoju relacji;

- lojalność zaangażowana z otwartością na rozwój relacji;

- lojalność z potencjałem rozwoju relacji;

- lojalność uśpiona.

Wskazane w modelu Siemieniako ${ }^{30}$ działania przedsiębiorstwa są powiązane w logice interaktywnej z postawami i działaniami po stronie klienta takimi jak: zaufanie ze strony klienta wobec usługodawcy oraz definiowanie i tworzenie wartości przez klienta. Budowanie zaufania klientów w usługach z intensywnym kontaktem jest złożonym zagadnieniem i wymaga szerszego spojrzenia na zagadnienie zaufania w wyniku rozpoznania różnych rodzajów tego zjawiska ${ }^{31}$. Ostatnim elementem modelu jest efekt w postaci różnych przejawów lojalności klienta wobec usługodawcy opartej na zobowiązaniu. Model nie precyzuje co prawda przejawów lojalności ze strony przedsiębiorstwa wobec klienta jako efektu końcowego całego procesu, jest to jednak wpisane w logikę działań przedsiębiorstwa według koncepcji zarządzania obietnicą.

\section{METODA BADAWCZA}

Wykorzystano dwie metody badawcze: wywiad swobodny i studium przypadku (case study research). W przeprowadzonych badaniach jakościowych zastosowano logikę indukcyjną, poszukując generalizacji na podstawie wniosków płynących z analizy szczególnych przypadków zarządzania relacjami z klientami ze wskazaniem na budowanie lojalności. Dobór próby badawczej był nielosowy, celowy. Celem badania było zweryfikowanie teoretycznego modelu zaproponowanego przez Siemieniako ${ }^{32}$ dotyczącego zarządzania lojalnością relacyjną opartą na zobowiązaniu w związkach usługowych w kontekście usług produkcyjnych, a zwłaszcza:

- ustalenie wpływu wzajemnego dopasowania usługodawcy i klienta na budowanie relacji;

- identyfikacja wpływu rozpoznawania potrzeb klienta na budowanie lojalności;

- rozpoznanie zależności pomiędzy koncepcją zarządzania obietnicą a lojalnością relacyjną;

- rozpoznanie postrzegania i ważności lojalności w usługach produkcyjnych B2B;

- identyfikacja działań świadczących o lojalności po stronie usługodawcy i klientów;

- rozpoznanie efektów lojalności relacyjnej dla usługodawcy i klienta.

\footnotetext{
${ }^{29}$ Ibidem.

${ }^{30}$ D. Siemieniako, Model..

${ }^{31}$ D. Siemieniako, Budowa zaufania klientów w warunkach niepewności na przykładzie kryzysu systemu finansowe go, ,Marketing i Rynek” 2009/7, s. 2-7.

${ }^{32}$ D. Siemieniako, Model...
} 
Wywiady swobodne częściowo ustrukturowane przeprowadzono z przedstawicielami 11 przedsiębiorstw od marca 2014 r. do lipca 2015 r. Zakres wywiadów obejmował wszystkie elementy teoretycznego modelu Siemieniako ${ }^{33}$. W badaniu wykorzystano scenariusz przeprowadzenia wywiadu. Jednostką badawczą było przedsiębiorstwo, a podmiotem badania zaś byli pracownicy - kadra menedżerska odpowiedzialna za relacje z najważniejszymi klientami, w szczególności: członkowie zarządu, menedżerowie ds. kluczowych klientów (Key Accounts Managers), dyrektorzy ds. sprzedaży oraz dyrektorzy ds. Badań i Rozwoju.

Spośród wszystkich badanych dziewięć przedsiębiorstw prowadziło wyłącznie lub jako jeden z kilku rodzajów, działalność polegającą na świadczeniu, w różnych systemach [takich jak: produkcja kontraktowa (CM, contract manufacturing), wytwarzanie oryginalnego wyposażenia (OEM, original erquipment manufacturing), projektowanie i wytwarzanie oryginalnego wyposażenia (ODM, original design manufacturing)], usług produkcyjnych na zlecenie przedsiębiorstw zachodnich (pochodzących z Europy Zachodniej i Stanów Zjednoczonych) będących właścicielami własnych marek handlowych. Tylko jedno badane przedsiębiorstwa prowadziło wyłącznie działalność produkcyjną wyrobów oferowanych pod własną marką. Jednym badanym przedsiębiorstwem (zachodni koncern) był odbiorca usług produkcyjnych.

Jeśli chodzi o branże działalności, to dziewięć badanych przedsiębiorstw reprezentowało branże związane z produkcją różnego typu urządzeń, maszyn i komponentów. W dwóch przypadkach były to branże, takie jak produkcja artykułów metalowych i materiałów budowlanych. Badane przedsiębiorstwa świadczące usługi produkcyjne były zlokalizowane w czterech dużych miastach na terenie Polski (300 000 mieszkańców i więcej). Badane były przedsiębiorstwa średniej i dużej wielkości pod względem liczby zatrudnionych pracowników i rocznych obrotów. Jeśli chodzi o własność, to w przypadku pięciu badanych przedsiębiorstw był to kapitał zagraniczny - zachodni, a w przypadku sześciu badanych przedsiębiorstw był to kapitał polski. Założeniem było także to, że badane przedsiębiorstwa oferowały usługi produkcyjne klientom zagranicznym, pochodzącym głównie z krajów zachodnich z wysoce rozwiniętą gospodarką. Tego typu usługi można zakwalifikować do usług B2B z intensywnym kontaktem, a relacja usługowa z założenia jest długoterminowa. Taki kontekst badania, związany z charakterystyką próby badawczej, pozwalał oczekiwać na pogłębioną weryfikację teoretycznego modelu Siemieniako ${ }^{34}$.

Studium przypadku zostało przeprowadzone na przykładzie dużego przedsiębiorstwa świadczącego usługi produkcyjne na zlecenie zachodnich koncernów z branży elektrotechnicznej. Przedsiębiorstwo to jest zlokalizowane w dużym polskim mieście. Studium przypadku przeprowadzono od marca 2014 do czerwca 2015 r. i wykorzystano wiele różnych metod jakościowych - można to działanie określić mianem triangulacji ze względu na to, że ,uzyskanie pogłębionego zrozumienia w metodzie studium przypadku wymaga zazwyczaj wykorzystania wielu metod badawczych w przekroju różnych przedziałów czasu, w których trwa badanie, tj. wykorzystanie triangulacji” ${ }^{35}$. Triangulacja obejmowała:

- $\quad$ metodę obserwacji uczestniczącej w środowisku objętym studium przypadku;

\footnotetext{
${ }^{33}$ Ibidem.

${ }^{34}$ Ibidem.

${ }^{35}$ A.G. Woodside, E.J. Wilson, Case study research methods for theory building, ,Journal of Business \& Industrial Marketing" 18/6-7 (2003), s. 498.
} 
- $\quad$ wywiady swobodne $\mathrm{z}$ menedżerami odpowiedzialnymi za relacje z klientami, zwłaszcza z bieżącymi i byłymi członkami zarządu, dyrektorem ds. rozwoju oraz menedżerem ds. kluczowych klientów; wywiady swobodne z przedstawicielami klientów badanego przedsiębiorstwa;

- metodę introspekcji badacza (researcher introspection) zalecaną w badaniach studiów przypadku ${ }^{36}$; w metodzie introspekcji własnej badacz analizuje post factum wypowiedziane przemyślenie oraz swoje zachowania wobec interlokutorów $\mathrm{z}$ badanego przedsiębiorstwa;

- $\quad$ analizę pisemnych dokumentów badanego przedsiębiorstwa.

\section{WYNIKI BADAŃ WLASNYCH METODAMI WYWIADU SWOBODNEGO I STUDIUM PRZYPADKU}

Zaproponowany przez Siemieniako ${ }^{37}$ model został poddany wielokrotnej konceptualizacji w trakcie prowadzenia badań, co umożliwiło pogłębione spojrzenie na ten model i lepsze zrozumienie elementów składowych wraz z powiązaniami w kontekście usług produkcyjnych B2B. Końcowym wynikiem przeprowadzonych badań jest model zarządzania relacjami w usługach produkcyjnych ze wskazaniem na budowanie lojalności relacyjnej, którego schemat zaprezentowano na rys. 1.

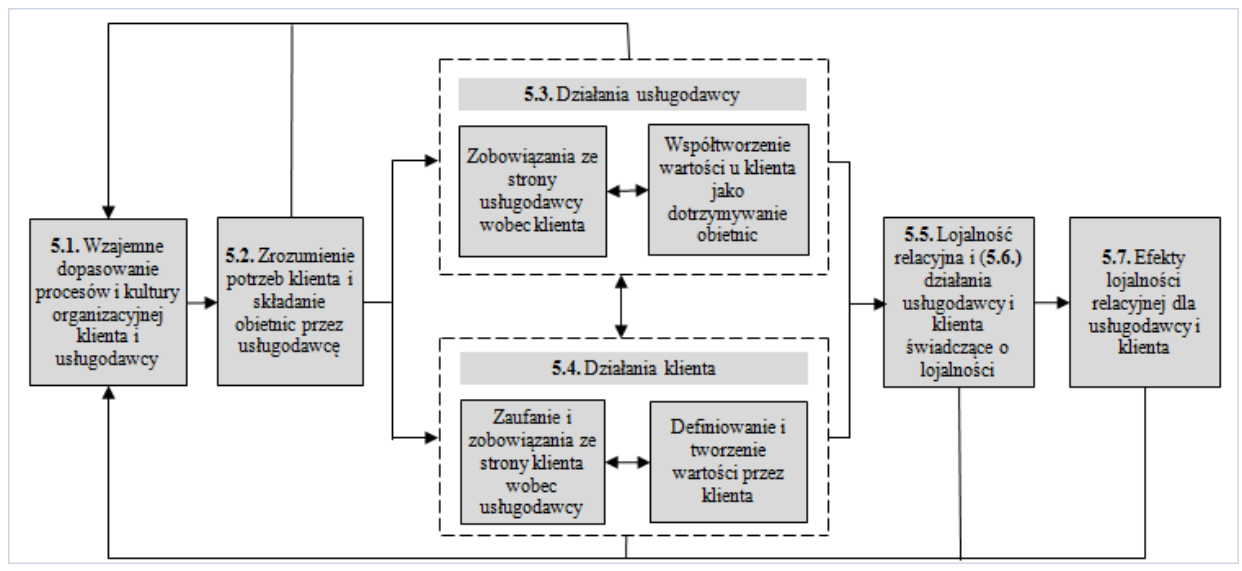

Rys. 1. Model zarządzania relacjami w usługach produkcyjnych ze wskazaniem na budowanie lojalności relacyjnej

Fig. 1. The model of relationship management in production services with direction on relational loyalty formation

Źródło: opracowanie własne na podstawie D. Siemieniako, Model zarzadzania lojalnościa relacyjna oparta na zobowiazaniu w zwiazkach ustugowych, „Marketing i Rynek” 2012/5, s. 8-14.

W dalszej części artykułu zostaną zaprezentowane wyniki w odniesieniu do poszczególnych elementów składowych modelu (rys. 1) oraz ich powiązań. Pomimo że przepły-

\footnotetext{
${ }^{36}$ Ibidem, s. 496

${ }^{37}$ D. Siemieniako, Model...
} 
wy elementów składowych modelu są ułożone w sekwencji działań, w zarządzaniu relacjami z klientami przedsiębiorstwa świadczące usługi produkcyjne realizują jednocześnie działania w ramach różnych składowych modelu. Na schemacie modelu znalazło to wyraz w sprzężeniach zwrotnych.

\subsection{Wzajemne dopasowanie procesów i kultury organizacyjnej klienta i usługodawcy}

Wyniki badania ukazały ważność wzajemnego dopasowania przedsiębiorstw świadczących usługi produkcyjne oraz ich klientów w wymiarach procesów zarządczych oraz kultury organizacyjnej w odniesieniu do zarządzania relacjami i budowania lojalności. Praktycznie wszyscy badani udzielający wywiadów podkreślali potrzebę uzyskania pogłębionej wiedzy o potencjalnym partnerze i jego otoczeniu rynkowym, zanim dojdzie do spotkania i współpracy.

„Bardzo ważne jest zdobycie jak największej wiedzy o kliencie, o otoczeniu biznesowym klienta, o rynku, na jakim działa, o jego problemach. Łatwiej wyjść naprzeciw potrzebom takiego klienta, zrozumieć je, dostosować do nich politykę i w długim terminie takiego klienta utrzymać”(W1).

„Często się spotykam z tym, że jak jadę do partnerów do Niemiec, to niemiecki kontrahent jest już przygotowany, więcej informacji ma o nas niż my o nim. I to jest właśnie już pierwszy błąd, jaki my robimy, że nie wiemy co, gdzie i jak on działał. Nawet czasami trzeba wiedzieć, kto jest właścicielem" (W2).

W wymiarze wzajemnego dopasowania na poziomie kultury organizacyjnej widoczny był wpływ różnic kultur narodowych pracowników przedsiębiorstw z Polski i krajów Europy Zachodniej. Kulturę narodową można potraktować jako składową kultury organizacyjnej. Jedna z badanych osób wskazywała na znaczącą trudność we współpracy ze względu na różne podejście do kategorii zaufania, jako koniecznego elementu współpracy, w odniesieniu do Polaków i przedstawicieli klientów z północnych krajów Europy Zachodniej, takich jak: Niemcy, Holandia, czy też kraje skandynawskie. Według tego badanego: „Jak nie ma zaufania, to nic nie będzie; są dwa podejścia do zaufania; według skandynawskiego czy holenderskiego na początku sobie ufamy, a potem potwierdzamy zaufanie i współpracujemy albo się rozstajemy - to jest skandynawskie; a polskie - czy też wschodnie - to na początku sobie nie ufamy, dopiero kolejne lata budują zaufanie; musimy mieć świadomość, że są dwa różne podejścia” (W7). Dalej ten sam badany zwraca uwagę, że jednym z kryteriów narzędzia NPS (net promotor score) służącego do budowania lojalności w B2B jest traktowanie drugiej strony w taki sposób, w jaki ta pierwsza chciałaby być traktowana i w „Naszej kulturze organizacyjnej, to się wydaje wielkie wyzwanie, a na Zachodzie, przynajmniej w Skandynawii, dla nich to żadne wyzwanie. Dla nas to jakieś narzędzie do budowy lojalności, systemy są potrzebne, a u nich to naturalne" (W7). Inny badany menedżer, pracujący dla polskiego przedsiębiorstwa świadczącego usługi produkcyjne, stwierdził, że „Kultura lojalności to kultura wyższa; poznałem w Polsce wielu biznesmanów bez wykształcenia, którzy stawiają na kombinowanie i nie są lojalni; lojalność to cecha ludzi kulturalnych; w biznesie jest to standard; często w kontaktach między firmami ze wschodniej i zachodniej Europy zdarza się, niestety, że firmy ze wschodniej Europy ukrywają problemy, nie mówią szczerze, że coś poszło niewłaściwie" (W2).

Także wypowiedzi innych badanych osób wskazywały na przedstawione różnice kultur narodowych, które szczególnie były istotne w procesie uzgadniania kontraktów oraz na początku współpracy. Kluczowego znaczenia nabiera tutaj kategoria zaufania. Badani 
ukazywali, w związku z ograniczonym zaufaniem, podejmowanie działań sprawdzających i kontrolnych przez zachodnie przedsiębiorstwa wobec polskich dostawców usług produkcyjnych, a dotyczące procesów produkcyjnych i produktów. W budowaniu zaufania na początku współpracy pomaga także pochodzenie - ta sama narodowość: „Łatwiej dla Niemca oferującego polskie produkty jest budować zaufanie z niemieckim kontrahentem niż dla Polaka mówiącego biegle po niemiecku i sprzedającego niemieckie produkty; ja jestem przedstawicielem w Polsce różnych firm z Niemiec i ludzie mówią: «Pan jest obcy, a Pan mówi świetnie po polsku, skąd Pan jest?». «Z Niemiec» - i od razu cena jest wyższa. Trochę tracę zaufanie na tym pierwszym kontakcie i tu jest ten dystans"(W2).

Różnice kulturowe w podejściu do zaufania, czy też do odpowiedzialności utrudniają dopasowanie się organizacji, które podejmują jednak współpracę ze względu na korzyści ekonomiczne. Można mówić o stopniowym dopasowywaniu się klienta i usługodawcy nie tylko przez pryzmat kultury organizacyjnej, ale także przez pryzmat różnych procesów, między innymi projektowych, produkcyjnych, logistycznych, dystrybucyjnych, których działania „zazębiają się” w obu organizacjach. Analiza studium przypadku, a także część wywiadów swobodnych pokazały, że w większości przypadków to zachodni klienci mają lepiej rozwinięte procesy od polskich usługodawców, choć na dzisiejszym konkurencyjnym rynku wymaga się od polskich przedsiębiorstw coraz wyższych standardów działania. Sytuacja ta zmusiła polskich przedsiębiorców do dostosowywania procesów do standardów zachodnich klientów. Doskonalenie procesów przez polskie przedsiębiorstwa wiązało się z nakładami finansowymi, ale przynosiło więcej wymiernych korzyści, które nie tylko były związane ze sprzedażą usług produkcyjnych dla tych klientów, ale także wiązały się ze wzrostem konkurencyjności polskich usługodawców. Jedna z badanych osób zwracała uwagę, że klient jego przedsiębiorstwa - zachodni koncern - blokował rozwój tych kompetencji polskiego przedsiębiorstwa, których nie potrzebował i w ten sposób wpływał na ograniczanie jego potencjału rozwoju. Wypowiedzi badanych menedżerów obrazują wskazane zależności.

„Jeżeli nie masz pewnego poziomu organizacyjnego - nikt z Tobą w ogóle nie rozmawia. Konieczne jest zaufanie do Ciebie oraz przekonanie, że jesteś efektywny, nowoczesny itd. Świat idzie tak mocno do przodu, że nikt nie chce tego, że ja mam być Twoim nauczycielem, nie chce się tego podjąć" (W4).

„Przy współrealizacji zamówienia, kiedy potrzebne jest pewne zazębienie się procesów klienta oraz firmy, to trzeba pewnej pracy z obu stron i terminowości wykonania tej pracy, jakości wykonania tej pracy" (W1).

,[...] potem już się dopasowują po iluś tam latach, ale na początku strony się męczą, nie rozumieją jedna drugiej, a nawet dużo jest przypadków, że próbują, próbują, ale nie dadzą rady, bo ta różnica kulturowa jest za duża. Wskazałbym na ten element opłacalności obu stron. Najpierw muszą być korzyści, żeby można było mówić o lojalności” (W6).

„Mówiłem, jak nasza firma działała nieefektywnie przed 2000 rokiem i potem pod wpływem nowego zachodniego właściciela i klienta - wielkiego koncernu z Niemiec jak to ewoluowało i muszę powiedzieć, że ta ewolucja utrwalała się w kulturze organizacyjnej firmy i przenosiła się na współpracę z innymi klientami i dostawcami” (W3).

„W naszej firmie wszystko było sfokusowane pod klienta - zachodni koncern, a to czego oni nie potrzebowali, tego nie mieliśmy. Strategia takich koncernów jest taka, żeby jego dostawcy mieli niepełne procesy, w sensie, żeby nie mogli obsługiwać kompleksowo innych klientów. Tak funkcjonuje Apple i tego nie ukrywa, nasz klient to ukrywa" (W5). 
Z wypowiedzi respondentów dotyczących kultury organizacyjnej, która sprzyja budowaniu lojalności, wynika, że jest to kultura oparta na dotrzymywaniu obietnic: „Tak to znaczy tak, nie to znaczy nie, bez ściemniania. Potwierdzanie każdego dnia, że to, co ustaliliśmy, to robimy. To chyba od tego się zaczyna, a potem każdego dnia potwierdzanie"(W7).

Jeszcze jednym elementem wzajemnego dopasowania, co było widoczne w analizowanym studium przypadku oraz na co zwracali uwagę badani menedżerowie, było dopasowanie na poziomie personalnym, przede wszystkim głównych przedstawicieli klienta i usługodawcy, ale także innych pracowników, którzy na równorzędnych stanowiskach mieli ze sobą kontakt. Wyniki badań umożliwiły wyróżnienie kryteriów dopasowania na poziomie personalnym: ta sama narodowość (o tym była już mowa), kwalifikacje językowe, kompetencje i doświadczenie merytoryczne, umiejętność ,poruszania się” w kulturze Zachodu poprzez interakcje zawodowe i osobiste, duża decyzyjność, dotrzymywanie obietnic jako spójność kontaktu personalnego z działaniami reprezentowanej firmy. Badani prezesi podkreślali, jak trudno pozyskać menedżera ds. kluczowych klientów, który spełniałby oczekiwania i właśnie chodziło o element dopasowania do przedstawicieli zachodnich klientów. Przytoczone wypowiedzi obrazują zagadnienie dopasowania na poziomie personalnym.

„Lojalność, zaufanie nie są utożsamiane z firmą. My nie mamy zaufania do firmy. My mamy zaufanie do człowieka, $\mathrm{z}$ którym mamy bezpośrednie relacje $\mathrm{w}$ tej firmie. Bo bardzo często ta lojalność ma swoją twarz. I to jest jakby cała podstawa. Bo jak w okresie kryzysu do mnie dzwonił dostawca i mówił tak: «Słuchaj, ja ci dam to na kredyt. Bo jak ty mi powiesz, że mi zapłacisz, się spóźnisz, ale mi zapłacisz, to ja ci wierzę»" (W1).

„Ja tam robię różne ustalenia i muszę stanąc na uszach czasami, żeby te ustalenia wdrożyć w życie, bo ja tam byłem, ja się z człowiekiem umówiłem, ja nie mogę teraz zawieść tego człowieka. Ja jechałem do człowieka, a nie do instytucji. Bez tych relacji personalnych, nie byłaby możliwa lojalność" (W3).

„Myśmy nawiązali pewną relację, on zrewanżował mi się tak, mówił: «Jak będziesz miał jakieś problemy, to dzwoń do mnie» itd. i zaczęliśmy ze sobą współpracować” (W4).

„W naszej firmie jest KAM. Nie spotkałem jeszcze Polaka odpowiednio przygotowanego do stanowiska KAM" (W8).

\subsection{Zrozumienie potrzeb klienta i składanie obietnic przez usługodawcę}

Większość badanych menedżerów stwierdziła, że empatia stron to nieodpowiednie słowo, odwołuje się bowiem do czynnika emocjonalnego, a w relacjach B2B największą rolę odgrywa model ekonomiczny. Jednak ze względu na wagę wzajemnego dopasowania na poziomie personalnym czynnik emocjonalny także ma znaczenie w budowaniu lojalności B2B. W wywiadach podkreślono wagę zrozumienia potrzeb klienta jako warunek lojalności. Jeden z badanych zwrócił uwagę na rozróżnienie zrozumienia i nadużywania. Tę kwestię ukazują następujące wypowiedzi:

„Ja empatię bardziej emocjonalnie postrzegam. W relacjach chodzi o coś pomiędzy empatią a chłodnym modelem biznesowym. Uważam, że emocje budują relację, pod warunkiem że są pozytywne" (W1).

„Lojalność to jest zrozumienie. Zrozumienie i trwanie w relacji. Bo jeśli jest zrozumienie, to jest możliwość trwania $\mathrm{w}$ relacji. Jeżeli nie ma zrozumienia, to przejściowe problemy powodują, że tej lojalności nie ma. Tu jest taka granica między zrozumieniem 
a nadużywaniem. My staramy się wytworzyć relacje oparte na zrozumieniu i żadna ze stron nie nadużywa tego, że jest zrozumienie z drugiej strony” (W1).

„Trzeba czuć i rozumieć osobę, z którą rozmawiasz. Im bliżej jest ona Twojego charakteru, tym lepszy jest z nią biznes. Jak masz wspólne tematy czy hobby, to już jesteś o jeden krok do przodu. To też jest kwestia wiekowa. Lepiej mi się rozmawiam z ludźmi w moim wieku niż z młodszymi lub starszymi. Oni mają inne historie, inne fryzury, inne dowcipy i można się nie zrozumieć" (W2).

Na podstawie analizy danych można stwierdzić, że zrozumienie stron na poziomach personalnym i organizacyjnym jest końcowym efektem procesu wzajemnego dopasowania. Na początku tego procesu są dwa różne podejścia, przyzwyczajenia, a na końcu procesu pozostaje jedno. Potrzebne są postawa i idące za tym działania otwartości i gotowości na wzajemne słuchanie i poszukiwanie najlepszych rozwiązań. Jeżeli polskie przedsiębiorstwa dostosowują się do procesów zarządczych zachodnich klientów (patrz podrozdział 5.1), to dlatego, że uznają ich większą efektywność i przewidują większe korzyści, a nie dlatego, że są do tego przymuszone. Badani przedstawiali jako pomocne w podejmowaniu zrozumienia potrzeb klienta następujące działania: częste spotkania bezpośrednie oraz dedykowanie odpowiednio przygotowanej osoby do zarządzania relacjami z kluczowymi klientami. Jeden z badanych ukazuje sukces efektu końcowego procesu dostosowania: „Na poziomie operacyjnym, po kilku latach, współpraca naszej firmy i kluczowego klienta jest taka, jakbyśmy byli jedną firmą, no, przesadziłem, ale w takim kierunku to idzie" (W3).

Brak zrozumienia pomiędzy stronami może prowadzić do „Próby uzyskania za wszelką cenę pozycji dominatora, żeby tego drugiego gnieść, jak się tylko da. [...] Ja myślałem, że to już nie istnieje, że to jest komunistyczna zaszłość, która już przeminęła, dopóki nie trafiłem do tej firmy i nie zobaczyłem, że to jest normalne" (W6). W tego typu przedsiębiorstwie z założenia nie wykazuje się zrozumienia klienta, bo strukturalnie przedsiębiorstwo to nie jest w stanie adekwatnie odpowiedzieć klientowi ,[...] i nawet im nie przeszkadza to, że widzą, że to w tej firmie nie działa. Wiele razy próbowali współpracy [z zachodnimi koncernami - dopisek D. S.] i na różnych poziomach to się kończyło, a zawsze się kończyło i generalnie bardzo szybko. Zawsze w świadomości tej firmy była to wina tamtej strony, bo albo za dużo wymagali, albo oszukiwali, albo nie wiadomo czego oczekiwali, to była ich wina i koniec. Firma ta nie ma wystarczającego bodźca i nigdy nie miała, żeby sprostać tej pierwszej fazie zmian, które muszą zaistnieć w organizacji, żeby ta współpraca mogła się rozwijać” (W6).

Analiza wywiadów i studium przypadku ukazała, że część zachodnich klientów rozwijała relację o charakterze partnerstwa z polskimi przedsiębiorstwami świadczącymi usługi produkcyjne, a część - przede wszystkim globalne koncerny - zarządzała relacjami z pozycji siły, gdzie widoczna jest nierównowaga stron w uzgadnianiu elementów współpracy. Badani menedżerowie podkreślali potrzebę zarządzania relacjami z klientami, zwłaszcza kluczowymi, w kierunku zwiększania relacji partnerskiej, co powinno przyczynić się do zachowania lojalności.

Według badanych składanie obietnic klientom powinno się odbywać z perspektywy zrozumienia potrzeb klientów. Kluczową kwestią jest składanie tylko takich obietnic, które będą dotrzymane, bo inaczej traci się wiarygodność. Na rynku usług produkcyjnych B2B w różnych branżach nie ma zbyt długiej listy potencjalnych klientów i z tego powodu informacje o polskich firmach usługowych jako dostawcach szybko rozchodzą się w konkretnych branżach. Złożone obietnice są systemowo monitorowane przez zachodnich 
klientów. Jeden z prezesów polskiego przedsiębiorstwa przedstawił następującą historię związaną ze składaniem obietnic menedżerowi potencjalnego klienta (dużego zachodniego koncernu): „Mamy określoną jakość, mamy określone zasoby, mamy fajny, młody zespół i mówię: «Czy masz jakiś projekt, który moglibyśmy wdrożyć?». On odpowiada: «Mam, ale będziesz musiał zainwestować $5 \mathrm{mln}$ zł». $5 \mathrm{mln}$ zł wtedy to była kwota niewyobrażalna dla naszej firmy. Stwierdziłem: «Nie ma problemu», a on mówi do mnie: «To trzymam cię za słowo, że mnie nie wyrolujesz». Jak zaczęliśmy budowę hali, to wyobraź sobie, że ja miałem człowieka, który chodził w piątek o godzinie 13:00 z aparatem fotograficznym, robił zdjęcia i o 14:00 te zdjęcia musiały być u tego klienta, dlatego że oni o 14:30 zaczynali ocenę projektową co piątek i dokumentacja fotograficzna była potwierdzeniem kroków, które ja raportowałem w sposób notatkowy, pisemny itd. Zajeżdżam $\mathrm{w}$ trakcie tego projektu do tego klienta, patrzę, z ostatniego tygodnia jest olbrzymia tablica na korytarzu - postępy prac w naszej firmie. Ktoś tam drukuje te zdjęcia, które ja co tydzień wysyłam i je zmienia. Jak mówię o zaufaniu, to obrazuje pewien poziom, jak to mówił towarzysz Stalin [wtrącenie po rosyjsku], czyli ufaj, ale sprawdzaj” (W4).

Klasyczne działania marketingowe, jak reklama, udział w targach mogą być pomocne przy pozyskiwaniu nowych klientów, natomiast w budowaniu lojalności liczy się „,Długoletnie budowanie procesu współpracy, zachowań, bycie podmiotem, na którym można polegać. Każdy chce w biznesie móc polegać na partnerze biznesowym. Uważam, że to zdecydowanie bardziej buduje relacje niż działania marketingowe. Działania marketingowe mają znaczenie w przypadku pozyskania nowego klienta. Natomiast później jest ciężka praca, żeby zbudować lojalność, relacje” (W1).

\subsection{Zobowiązania ze strony usługodawcy i współtworzenie wartości u klienta jako dotrzymywanie obietnic}

$\mathrm{Na}$ pierwszym poziomie zobowiązania wobec uznawanych norm i przekonań ${ }^{38}$ w relacjach B2B polskich przedsiębiorstw świadczących usługi produkcyjne oraz zachodnich klientów badani menedżerowie zwracali uwagę na konieczność dotrzymywania obietnic we współpracy. Bardzo wyraźnie wynika z wywiadów i studium przypadku, że jest to normą wśród zachodnich przedsiębiorstw, jak to jeden z badanych stwierdził: „Jest taka etykieta, jak damy rękę i mówimy na twarz, że ma być czarne, to ma być czarne, jak ma być czerwone, to ma być czerwone. I każda zmiana, w każdym kierunku jest problemem. Taka etykieta ustna, trzeba mocno brać ją pod uwagę" (W2).

Kolejnym poziomem zobowiązania jest zobowiązanie jako postawa wdzięczności. Badani menedżerowie zwracali uwagę na podejmowanie wzajemnych zobowiązań z klientami jako wyrazu odwzajemnienia lub wdzięczności za wcześniejsze zachowania lub działania na korzyść drugiej strony. Dotyczyło to zwłaszcza sytuacji problemowych, w których w imię zaufania i lojalności jeden z partnerów wychodził drugiemu naprzeciw. Przytoczone wypowiedzi odnoszą się do zobowiązań jako postawy wdzięczności.

„W sytuacji kryzysowej dostawcy okazali się w stosunku do nas lojalni. Pomimo że nasze opóźnienia w płatnościach sięgały nawet do 4 miesięcy, oni czekali na swoje pieniądze, wiedzieli, że je dostaną. Dostawcy czuli się zobowiązani, bo wcześniej my wspieraliśmy ich rozwój. To zobowiązanie do bycia wdzięcznym może budować lojalność, na zasadzie takiej, że klient czuje się zobowiązany" (W1).

\footnotetext{
${ }^{38}$ D. Siemieniako, Typy...
} 
„Pamiętam też, że kilka razy on [przedstawiciel klienta - dużego zachodniego koncernu] ustąpił i zrobiło mi się głupawo i wtedy mówię: «Dobra, teraz ja pasuję, ale on częściej». Jak była do uzgodnienia kwestia mocno nieklarowna, to on wolał ustąpić. Pomimo pirackiego i bardzo restrykcyjnego podejścia ze strony tego klienta, to potrafił ustąpić" (W5).

„Załatwienie problematycznej sprawy dla klienta to jest zawsze inwestycja na przyszłość. To jest wyrazem zaufania, lojalności i owocnej współpracy. Nie można patrzeć tylko jednostronnie" (W2).

Wyniki badań pokazały, że w kulturze współpracy z odbiorcami z Zachodu jednym z kluczowych elementów budowania relacji jest podejmowanie i dotrzymywanie zobowiązań jako deklaracji słownej. Wyraźnie jest to widoczne w wypowiedzi jednej z badanych osób: „Nie przypominam sobie, żeby kiedykolwiek, chociaż o jeden dzień, klient koncernowy z Niemiec, przedłużył czy nie dopełnił swojego zadania. I to bez żadnych obietnic, że ja tu na pewno się postaram - normalne, chleb z masłem. Pisałem raporty ze spotkań z tym klientami, po to, żebym nie zapomniał, do czego się zobowiązałem, bo byłoby mi strasznie głupio i wstyd. W ten sposób to ja rozumiem, że ja byłem lojalny wobec nich, bo oni mnie do tego zmobilizowali. Oczywiście miałem ogromne problemy z przełożeniem tego u siebie w firmie, bo wiele rzeczy było niezależnych ode mnie" (W3).

Ostatnim poziomem zobowiązania jest zobowiązanie kontraktowe. Część respondentów wskazywała, że to właśnie kontrakt i konkurencyjność oferty najmocniej wpływają na relację biznesową w usługach produkcyjnych i że lojalność między stronami nie jest potrzebna i nie występuje. Jednak według większości badanych osób relacja bazująca wyłącznie na zapisach kontraktowych jest elementem niewystarczającym w uzyskaniu obustronnie korzystnej współpracy. Oczywiście korzyść ekonomiczna, do której odwołuje się kontrakt, jest podstawowym warunkiem współpracy, ale bez zaufania, zaangażowania i lojalności nie można uzyskać zadowalających wyników w ramach długotrwałej współpracy. Badani wyraźnie wskazywali, że jeżeli nie ma korzyści ekonomicznej ze współpracy, to lojalność sama w sobie nie wystarczy: ,[...] nie jesteśmy tutaj dla lojalności, ale lojalność jest pewnym stylem uprawiania relacji” (W1). Ten sam menedżer zwracał uwagę, że w działaniach świadczących o lojalności nie chodzi o poświęcenie, tylko o inwestycję na przyszłość, budowanie biznesu, „Bo jeśli ktoś chce budować biznes, który ma funkcjonować w dłuższym okresie czasu, to nie jest jeden deal chwilowo - mam coś na zbyciu, dobrze ja tu się poświęcę. Moim zdaniem to jest budowanie relacji i budowanie biznesu. To jest inwestycja w przyszłość tak naprawdę. W momencie, kiedy ten klient będzie coś potrzebował, albo będzie się rozwijał to w pierwszej kolejności, on przyjdzie do mnie" (W1).

Wyniki badania pokazały, że budowanie lojalności wymaga prowadzenia wszelkich działań przez badanych usługodawców wobec klientów w logice dotrzymywania obietnic. Działania usługodawców były prowadzone w procesie realizacji usług i jak zauważył jeden $\mathrm{z}$ badanych: „Dotrzymywanie obietnic odbywa się w procesie realizacji; to, co klientowi obiecujemy, to dostarczamy, czyli terminowe realizowanie zamówień, zgodnie ze specyfikacją; to jest właśnie budowanie tej lojalności, zaufania, wiarygodności” (W1). Dotrzymywanie obietnic stanowi więc jednocześnie warunek oraz jest wyrazem współtworzenia wartości u klienta ${ }^{39}$, czyli maksymalizowania korzyści klienta w związku ze współpracą. Badani menedżerowie wskazywali na istotność wielu elementów we współtworzeniu przez usługodawców wartości u klientów, takich jak: transparentność usługo-

\footnotetext{
${ }^{39}$ C. Grönroos, Search...
} 
dawcy i sposobów jego działania, zaangażowanie i inicjatywa usługodawcy w procesach realizacyjnych, stałość jakości relacji, kompetencje i zrozumienie kulturowe na poziomie zarządzania relacjami z kluczowymi klientami. Jeden z badanych menedżerów podkreślał zależność pomiędzy zwiększaniem współtworzenia wartości u klientów koncernowych a poprawą swojej pozycji w relacji z tym klientem na bardziej równorzędną.

\subsection{Zaufanie i zobowiązania ze strony klienta wobec usługodawcy oraz definiowanie i tworzenie wartości przez klienta}

Wyniki badania jednoznacznie wskazały, że zaufanie klientów jest warunkiem ich lojalności i powstaje jako reakcja na działania usługodawcy w procesach wzajemnego dostosowania i realizacji usług produkcyjnych. Zaufanie może rosnąć lub maleć. Badani menedżerowie mocno akcentowali różnice kulturowe w podejściu do zaufania przedsiębiorstw zlokalizowanych w Polsce i krajach Europy Północno-Zachodniej, co zostało omówione w rozdziale 5.1. Klienci z krajów zachodnich w celu minimalizacji konieczności zaufania podejmowali według badanych wiele działań sprawdzających, między innymi monitoring procesów realizacyjnych usługodawców ze wskaźnikami wczesnego ostrzegania.

Wyniki badania pokazały elementy przyczyniające się do wzrostu zaufania. Oprócz generalnego dotrzymywania obietnic, zaufanie klientów szczególnie wzrastało, jeśli usługodawca był transparentny w rozumieniu nie tylko umożliwiania klientom wizyt referencyjnych, ale przede wszystkim w pokazywaniu swoich głównych procesów funkcjonalnych, struktury organizacji, kosztów, zwłaszcza kosztów zakupu surowców i komponentów oraz bazy dostawców. W zwiększaniu zaufania klientów zachodnich wobec polskich usługodawców pomagało pośrednictwo w inicjowaniu relacji przez wiarygodne dla tych klientów organizacje, co potwierdziły analiza studium przypadku i wypowiedź jednej z osób udzielających wywiadu. Wreszcie podpisanie umowy poufności (nda, non disclosure agrement) zostało wskazane jako narzędzie pomocne w podejmowaniu działań opartych na zaufaniu. Przytoczone wypowiedzi odnoszą się do przedstawionych wniosków.

„Prosili nas, sugerowali, ale nie mocno naciskali, żeby nam się nie narazić, na to, żeby się coraz więcej im otworzyć, coraz więcej pokazać naszych kosztów, naszych procesów. Myśmy się bardzo długo przed tym bronili, wiedząc, po co takie firmy o to proszą. Trwało to lata, ale zrozumieliśmy, że wszyscy na tym mogą zyskać, bo my otwieraliśmy się, pokazywaliśmy im swoje kanały dystrybucji, kanały zakupowe i koszty zakupu poszczególnych materiałów czy komponentów i w ten sposób odkrywaliśmy się i mogli poznać nasze koszty i mogli to wykorzystywać. I oni, przynajmniej ja nie zauważyłem, żeby wykorzystywali to na naszą niekorzyść, wręcz przeciwnie, popatrzyli na to, to oczywiście był proces i powiedzieli «Słuchajcie, wiecie co, Wy to kupujecie drogo, a my możemy Wam dać naszego dostawcę i będziecie kupować 30\% taniej»” (W3).

„Polska jest wciąż traktowana z dużą dozą nieufności. Często ludzie z dużych koncernów nie dowierzają, że my możemy spełnić pewne normy jakościowe. [...] następuje wizyta, gdzie koncerny chcą obejrzeć zakład i ocenić jego poziom organizacyjny, techniczny, kulturowy. Zaufanie rozpoczyna się od tego, że podpisujemy nda [umowę poufności] - to jest podstawowy dokument, bez tego dalej nie ma ani jednego kroczku. To nda podpisuje się dopiero po wizycie" (W4).

„Są organizacje w Niemczech, które proponują np. firmy z Polski czy z innego kraju i taki jest ten pierwszy kontakt. To jest bardzo ważne - jak jest kontakt przez takie organizacje, to już jest pierwszy krok do zaufania i wtedy jest większy interes” (W2). 
Podobnie jak zaufanie, zobowiązania klientów powstają także jako reakcja na zobowiązania ze strony usługodawców, co zostało przedstawione w rozdziale 5.3. Analiza treści wywiadów i studium przypadku pozwoliła wyciągnąć wniosek, że liczba i istotność zobowiązań zachodnich klientów powstaje w miarę dostosowywania się procesów polskich dostawców usług produkcyjnych do systemów tych klientów, ponieważ wtedy klienci mogą uzyskiwać większe korzyści ze współpracy, czyli mogą tworzyć dla siebie większą wartość. Spójność procesów obu stron relacji umożliwia klientom zachodnim bardziej precyzyjne definiowanie wartości (korzyści) uzyskiwanej ze współpracy z polskim dostawcą usług produkcyjnych w stosunku do wartości uzyskiwanych od innych dostawców, na przykład z Chin. Dostosowanie procesów obu stron było przedstawiane w wywiadach jako zdecydowanie ważniejsze w zarządzaniu relacjami niż istnienie zobowiązań kontraktowych. Wyniki badania pokazały wyraźnie, że doskonalenie głównych procesów przez polskie przedsiębiorstwa świadczące usługi produkcyjne, na wzór procesów zachodnich klientów wiązało się z dużymi trudnościami. Jedna $\mathrm{z}$ badanych osób ukazała proces zaangażowania zachodniego klienta w dostosowywanie procesów bez istnienia kontraktu.

„[...] to wszystko jest zaprzęgnięte w procesy. Natomiast bardzo istotnym elementem jest to, że z tamtej strony jest jedna osoba oddelegowana do budowy relacji z klientem. Oczywiście, ta osoba tak to wszystko organizuje, że w odpowiednich momentach wplata później inne osoby i potem to się robi taki szeroki krok. Już siedem lat mojej współpracy $\mathrm{z}$ tą firmą $\mathrm{i}$ wciąż ten sam człowiek $\mathrm{z}$ tej firmy współpracuje $\mathrm{z}$ nami. I w pewnym momencie to się nawet zapomina, że się współpracuje z ogromną korporacją, tylko że się współpracuje z tym człowiekiem" (W3).

„Nie mieliśmy z nimi żadnej umowy pisemnej, na zasadzie kontraktu, że będziemy kupować tyle i tyle, na takich warunkach. Okres dochodzenia do współpracy, początek współpracy i potem lata współpracy tak były prowadzone i to głównie przez tego klienta, tak uczciwie, rzetelnie, profesjonalnie i po partnersku przede wszystkim, że wszyscy widzieli w tym korzyść dla współpracy i chciało się dalej z nimi współpracować, a z tego, co oni mówili, to i im z nami” (W3).

„Liczą się ich zaufanie i wartość dla nich. Będą nas naciskać, po to, żeby nasza współpraca mogła być długa i trwała, żebyśmy razem mogli być konkurencyjni na rynku, a przy tej okazji całe otoczenie naszego biznesu też staje się bardziej konkurencyjne, bo wdraża coraz lepsze systemy" (W3).

\subsection{Lojalność relacyjna klienta i usługodawcy}

Jak pokazano na modelu (rys. 1), dalszą konsekwencją zarządzania relacjami w usługach produkcyjnych jest powstawanie lojalności relacyjnej klientów i usługodawcy. Według deklaracji badanych osób na początku wywiadów relacje B2B w usługach produkcyjnych mogą być oparte na lojalności lub nie. Trzech badanych menedżerów stwierdziło, że relacjami „rządzi” przede wszystkim kontrakt oraz konkurencyjność oferty dostawcy usług: jakość usług, niskie koszty wytwarzania, elastyczność (rozumiana przede wszystkim jako szybkość świadczenia usług). Dwóch z nich było pracownikami dużych zachodnich koncernów. Według jednego z badanych, którzy twierdzili, że relacjami biznesowymi nie kieruje lojalność: ,,[...] na pierwszym miejscu stawia się sprawy ekonomiczne, czyli konkurencyjność cenową i jakościową. W mojej branży dodałbym aspekt designu i jakości wykonania" (W4). W ramach przeprowadzonego studium przypadku przedstawiciel klienta - dużego zachodniego koncernu, wskazywał na generalną politykę 
tego przedsiębiorstwa wobec dostawców usług produkcyjnych: „Jeżeli nasza firma zarządza relacjami z dostawcą, który popełni błąd w danym produkcie, to nie ma zmiłuj się, wycina się całą linię produktową od tego dostawcy i przechodzi się do nowego dostawcy. Przede wszystkim liczy się konkurencyjność oferty, spisuje się kontrakt i to utrzymuje relację. Nie ma miejsca na lojalność w usługach produkcyjnych między organizacjami” (W11).

W dalszej części wywiadów badani, którzy na początku stwierdzali, że w relacjach biznesowych nie ma miejsca na lojalność, przedstawiali jednak sytuacje, w których ukazywali występowanie zaufania i lojalności między stronami jako istotne elementy zarządzania relacjami B2B. Biorąc pod uwagę wszystkie przeprowadzone wywiady można stwierdzić, że pojęcie lojalności było różnie rozumiane, a także istotność lojalności w relacjach B2B była różnie postrzegana. Część badanych nadawała węższe znaczenie lojalności, jednak większość osób udzielających wywiadów szerzej rozumiało lojalność w relacjach B2B w usługach produkcyjnych.

Ta pierwsza grupa akcentowała prowadzenie działalności z dotrzymywaniem różnych zobowiązań (patrz podrozdział 5.3) jako przejaw lojalności, a także zwracano uwagę na uczciwość, transparentność i otwartość w relacjach biznesowych jako tożsame z lojalnością.

Tabela 1. Cechy i charakterystyka lojalności relacyjnej w usługach produkcyjnych

Table 1. Features and characteristics of relational loyalty in production services

\begin{tabular}{|c|c|c|}
\hline Lp. & \begin{tabular}{|c|} 
Cechy lojalności \\
relacyjnej w usłu- \\
gach produkcyjnych
\end{tabular} & $\begin{array}{l}\text { Charakterystyka lojalności relacyjnej } \\
\text { w usługach produkcyjnych }\end{array}$ \\
\hline 1. & $\begin{array}{l}\text { Lojalność to przede } \\
\text { wszystkim zachowanie }\end{array}$ & $\begin{array}{l}\text { W kontekście usług produkcyjnych przede wszystkim działania (za- } \\
\text { chowania) stron świadczą o lojalności; jednak postawa lojalności także ma } \\
\text { znaczenie, zwłaszcza w aspekcie personalnym lojalności }\end{array}$ \\
\hline 2. & Wzajemność lojalności & $\begin{array}{l}\text { Lojalność ma charakter relacyjny; jest okazywana najpierw przez usłu- } \\
\text { godawcę wobec klienta, a lojalność od klienta wobec usługodawcy wypły- } \\
\text { wa jako odwzajemnienie }\end{array}$ \\
\hline 3. & $\begin{array}{l}\text { Powstawanie } \\
\text { w długim ter }\end{array}$ & $\begin{array}{l}\text { Długoterminowość relacji wiąże się ze specyfiką usług produkcyjnych; } \\
\text { lojalność w tych relacjach ewoluuje w miarę upływu czasu i potwierdzania } \\
\text { przez strony satysfakcjonującej i korzystnej relacji biznesowej }\end{array}$ \\
\hline 4. & $\begin{array}{l}\text { Trwało } \\
\text { lojalnos }\end{array}$ & $\begin{array}{l}\text { Dbałość o utrzymanie relacji, zwłaszcza w momentach kryzysowych; } \\
\text { trwanie relacji w dłuższej perspektywie }\end{array}$ \\
\hline 5. & $\begin{array}{l}\text { Lojalność widoczna jest } \\
\text { w zachowaniach w } \\
\text { kontekstach sytuacyj- } \\
\text { nych }\end{array}$ & $\begin{array}{l}\text { Lojalność wyraża się poprzez decyzje jednej strony relacji w odniesie- } \\
\text { niu do konkretnych sytuacji związanych z drugą stroną relacji; dotyczy to } \\
\text { zwłaszcza sytuacji kryzysowych; czyli można zachować się albo lojalnie, } \\
\text { albo nielojalnie; w zachowaniu lojalnym można też mówić o stopniowaniu } \\
\text { lojalności }\end{array}$ \\
\hline 6. & Złożoność lojalności & $\begin{array}{l}\text { Lojalność może być okazywana wobec różnych obiektów; lojalność or- } \\
\text { ganizacyjna występuje między przedsiębiorstwami i wyraża się w decy- } \\
\text { zjach zarządczych wpisanych w model współpracy między stronami; lojal- } \\
\text { ność personalna występuje między pracownikami obu stron relacji }\end{array}$ \\
\hline 7. & $\begin{array}{l}\text { Zróżnicowana dynami- } \\
\text { ka spadków i wzrostów } \\
\text { lojalności }\end{array}$ & $\begin{array}{l}\text { Lojalność może szybko maleć lub zaniknać między stronami, a rosnáć } \\
\text { w dłuższej perspektywie czasu; często natychmiastowy spadek lojalności } \\
\text { wiąże się najczęściej z negatywną oceną konkretnych epizodów zachodzą- } \\
\text { cych między stronami relacji; wzrost lojalności wiąże się z działaniami } \\
\text { odbudowywania relacji; relacja może trwać bez lojalności na bazie stwo- } \\
\text { rzonych barier wyjścia }\end{array}$ \\
\hline 8. & $\begin{array}{l}\text { Lojalność to styl budo- } \\
\text { wania relacji }\end{array}$ & $\begin{array}{l}\text { W nawiązaniu relacji konieczne są zaufanie i korzyść dla każdej ze } \\
\text { stron; zarządzanie relacją B2B może odbywać się z uwzględnieniem budo- } \\
\text { wania lojalności między stronami lub na bazie zapisów kontraktowych i }\end{array}$ \\
\hline
\end{tabular}




\begin{tabular}{|l|l|l|}
\hline 9. & $\begin{array}{l}\text { Występowanie lojalno- } \\
\text { ści na różnych pozio- } \\
\text { mach struktury organi- } \\
\text { zacji }\end{array}$ & $\begin{array}{l}\text { Na poziomie zarządczym można mówić o oficjalnych relacjach między } \\
\text { stronami, w których występuje lojalność; a na poziomie operacyjnym } \\
\text { niezależnie od poziomu zarządczego lojalność można określić jako relację } \\
\text { powstającą pomiędzy pracownikami na odpowiadających sobie stanowi- } \\
\text { skach pracy }\end{array}$ \\
\hline
\end{tabular}

Według przedstawicieli drugiej, wspomnianej już grupy badanych lojalność ma szersze znaczenie ponad to, co przedstawili badani z pierwszej grupy. Szersze rozumienie wraz z postrzeganiem istotności lojalności w relacjach biznesowych wiązało się z:

- dostrzeganiem wpływu nie tylko kontraktu, ale także elementów miękkich relacji, takich jak: zaufanie, zaangażowanie i lojalność, na trwałość, jakość relacji i satysfakcję z relacji;

- występowaniem sytuacji kryzysowych jednej ze stron relacji, w których zachowania oparte na lojalności są bardzo ważne;

- $\quad$ z powiązaniem poziomu wzajemnej lojalności z wynikami finansowymi, wielkością sprzedaży, rentownością relacji oraz wzrostem konkurencyjności.

Wybrane wypowiedzi odnoszące się do tego stwierdzenia: „W moim rozumieniu lojalność to jest takie przywiązanie klienta do siebie, ale bez sznurka, tylko na zasadzie takich relacji, że klient chce współpracować z nami; nie sznurkiem, nie na siłę; tylko takimi mechanizmami, sposobami, które zachęcają go do tego” (W7); „Miarą prawdziwej lojalności nie jest dobrobyt, prosperity. Ta lojalność prawdziwa objawia się wtedy, kiedy jest problem. Miarą lojalności i sprawdzeniem lojalności są sytuacje kryzysowe. Pokazują one, jaką lojalność udało nam się zbudować - czy ona jest na twardych fundamentach, czy jest iluzoryczna" (W1).

Biorąc pod uwagę wszystkie wyniki przeprowadzonych badań, można wyróżnić charakterystyczne cechy lojalności relacyjnej w usługach produkcyjnych (tab. 1). Cechy i charakterystykę lojalności rozpoznano na podstawie wypowiedzi badanych menedżerów. Niektóre cechy lojalności były inaczej postrzegane przez różnych badanych, co znalazło wyraz w charakterystyce konkretnej cechy.

Na podstawie analizy wyników badań można też wskazać na czynniki poprzedzające (antecedens) lojalność. Obok trzech typowych, które występują w literaturze przedmiotu, takich jak: zaufanie, zaangażowanie i satysfakcja, zidentyfikowano w badanym kontekście usług produkcyjnych także inne istotne czynniki poprzedzające jako warunki powstawania lojalności:

- czynniki kulturowe różnicujące strony relacji ze względu na różne narodowości i różną kulturę organizacyjną,

- umiejętność zrozumienia (a w niektórych sytuacjach nawet empatii) ze strony personelu usługodawcy wobec usługobiorcy - „Lojalność w usługach produkcyjnych budują ludzie"(W1).

\subsection{Działania usługodawcy i klienta świadczące o lojalności}

Sposób rozumienia lojalności relacyjnej oraz postrzeganie przez osoby udzielające wywiadów poziomu wpływu tego zjawiska na sukces zarządzania relacjami oraz wyniki całego przedsiębiorstwa wyznaczało zaangażowanie badanych usługodawców w podejmowanie działań świadczących o lojalności. Działania te były wpisane w program zarządzania relacjami i służyły podtrzymywaniu i wzmacnianiu wzajemnej lojalności. Zidenty- 
fikowane działania usługodawców i klientów świadczące o lojalności można zakwalifikować do pięciu kategorii:

1) zrozumienie drugiej strony, doskonalenie procesów po stronie usługodawców i wzrost konkurencyjności obu stron;

2) podejmowanie i dotrzymywanie zobowiązań;

3) nieprowadzenie działań na szkodę drugiej strony;

4) aktywne podejście do sytuacji kryzysowych po drugiej stronie;

5) pogłębianie lojalności.

Zidentyfikowane $w$ badaniach działania dotyczące (1) zrozumienia drugiej strony, doskonalenia procesów po stronie usługodawców i wzrostu konkurencyjności obu stron to:

- działania usługodawców:

- $\quad$ pozyskanie i prezentowanie zachodnim klientom wiedzy i zrozumienia dotyczących ich sytuacji i branży;

- transparentność własnej organizacji; otwartość wobec klientów; udostępniania wiedzy o własnych procesach zarządzania (m.in. produkcyjnych, projektowych) i kosztach (m.in. zakupu surowców komponentów);

- zaangażowanie w maksymalizowanie wartości u klientów, na przykład inicjatywy doskonalenia projektów produktów klientów;

- działania klientów:

- oferowanie usługodawcom bardziej konkurencyjnych (głównie cenowo) własnych dostawców;

- pozostawanie tolerancyjnym pomimo błędów usługodawców;

- akceptacja podwyżek cenowych usługodawców uwarunkowana dostrzeganiem przez klientów działań świadczących o lojalności ze strony usługodawców.

$\mathrm{W}$ ramach kategorii (2) podejmowanie i dotrzymywanie zobowiązań rozpoznano następujące działania świadczące o lojalności:

- działania zarówno usługodawców, jak i klientów:

- generalnie dotrzymywanie deklaracji i uzgodnień słownych lub w formie notatek, zanim jeszcze dojdzie do zobowiązań kontraktowych - dotyczy to zwłaszcza polskich przedsiębiorstw świadczących usługi produkcyjne, ponieważ częstymi problemami kultury organizacyjnej tych przedsiębiorstw są brak dotrzymywania zobowiązań słownych oraz problemy z jednoznacznością odpowiedzialności;

- podejmowanie i realizacja zobowiązań wobec drugiej strony jako wyrazu wdzięczności lub odwzajemnienia za wcześniej dostarczone korzyści przez tę stronę;

- działania usługodawców:

_ $\quad$ informowanie klientów o ewentualnym niedotrzymywaniu obietnic;

- $\quad$ prowadzenie procesu reklamacji klientów w kulturze dotrzymywania obietnic;

- $\quad$ w sytuacjach problemowych w ramach bieżącej współpracy rzetelne informowanie klientów - nieukrywanie problemów.

Wyniki badania pokazują, że budowanie lojalności wymaga (3) nieprowadzenia działań na szkodę drugiej strony. Zidentyfikowano następujące działania tego typu:

- działania usługodawców:

- generalnie niepodejmowanie działań na szkodę klientów ze względu na doraźny zysk; 
- $\quad$ nieprowadzenie sprzedaży za wszelką cenę, co zostało określone jako „,brudny zysk" (W1);

- działania klientów:

- nieblokowanie usługodawcom możliwości pozyskiwania zleceń na usługi produkcyjne od innych klientów; można dopuścić pewne wyłączenia, na przykład bezpośrednią konkurencję klientów;

- $\quad$ kończenie współpracy z usługodawcami z minimalizacją ich strat.

Istotnym kontekstem realizacji działań świadczących o lojalności zarówno usługodawców, jak i klientów jest sytuacja kryzysowa, w której może się znaleźć jedna ze stron. Zrozumienie, wyjście naprzeciw, zaangażowana pomoc, czyli (4) aktywne podejście do sytuacji kryzysowych po drugiej stronie, wyznacza wiele działań zarówno po stronie usługodawców, jak i klientów świadczących o lojalności, jako że „Miarą lojalności i sprawdzeniem lojalności są sytuacje kryzysowe" (W1).

Ostatnią kategorią działań usługodawców i klientów świadczących o lojalności są działania związane z (5) pogłębianiem lojalności:

- działania usługodawców:

- $\quad$ utrzymanie jakości relacji na stałym poziomie;

- $\quad$ wyrażanie bezinteresowności w kontaktach z klientami; innymi słowy - podejmowanie działań nie tylko ze względu na własny interes; oraz podejmowanie pewnych działań dla dobra drugiej strony, nie licząc się z własnymi korzyściami;

- $\quad$ okazywanie szacunku wobec klientów oraz docenienie korzyści uzyskiwanych ze współpracy;

- działania klientów:

- $\quad$ wykazywanie odporności na zachęty innych dostawców usług produkcyjnych;

- $\quad$ przekazywanie usługodawcom nowych zleceń produkcyjnych;

- udzielanie referencji innym potencjalnym klientom usługodawców;

- $\quad$ wyrażenie zgody dla usługodawców na prezentowanie istniejącej współpracy innym potencjalnym klientom podczas wizyt referencyjnych.

\subsection{Efekty lojalności relacyjnej dla usługodawcy $i$ klienta}

Ostatnim elementem modelu zarządzania relacjami w usługach produkcyjnych ze wskazaniem na budowanie lojalności relacyjnej (rys. 1) są efekty lojalności relacyjnej dla usługodawcy i klienta. Analiza wyników badań metodami wywiadu swobodnego i studium przypadku pozwoliła na rozpoznanie następujących obustronnych efektów zarządzania relacjami i budowania lojalności między usługodawcami a klientami:

- poprawa jakości relacji;

- bardziej płynne dostosowanie procesów przez polskich usługodawców do standardów zachodnich klientów;

- stworzenie przez przedsiębiorstwa świadczące usługi produkcyjne większych

barier wyjścia z relacji dla klientów;

- zwiększenie trwałości relacji;

- wzrost wartości sprzedaży i wzbogacenie portfela produkcji usługodawców, dzięki nowym zleceniom projektów produkcyjnych od zachodnich klientów; 
- poprawa wyników finansowych po obu stronach dzięki obniżeniu kosztów współpracy (np. korzystanie z tańszych dostawców lub lepsza optymalizacja materiałowa dzięki doskonaleniu projektowania produktów);

- poprawa wyników finansowych po obu stronach dzięki udoskonaleniu procesów usługodawców;

- wzrost konkurencyjności po obu stronach relacji; po stronie polskich przedsiębiorstw wzrost konkurencyjności dzięki doskonaleniu procesów i dostępu do tańszych dostawców;

- referencje ze strony zachodnich klientów;

- ułatwienie przejścia przez sytuacje kryzysowe dzięki wsparciu lojalnych partnerów.

\section{ZAKOŃCZENIE}

Przedstawione wyniki badań ukazały znaczenie, istotność oraz złożoność zarządzania relacjami B2B w usługach produkcyjnych ze wskazaniem na budowanie lojalności przy wykorzystaniu modelu koncepcyjnego Siemieniako ${ }^{40}$. W zakończeniu artykułu warto zwrócić uwagę, że badani menedżerowie przedsiębiorstw świadczących usługi produkcyjne wskazali także na potrzebę dostosowania systemu zarządzania $\mathrm{w}$ organizacji do efektywnego zarządzania relacjami z budową lojalności. Szczególnie dotyczyło to:

- kultury organizacyjnej z kulturą lojalności wobec pracowników i klientów;

- roli przywództwa (leadership) w organizacji oraz dbałości o lojalność pracowników, którzy dzięki temu wyrażają lojalność wobec klientów;

- formułowania strategii przedsiębiorstwa, w którą powinno być wpisane budowanie lojalności relacyjnej, na przykład jako jeden z celów strategicznych;

- zmian w strukturze organizacyjnej w kierunku adaptacji zarządzania relacjami z naciskiem na budowanie lojalności; między innymi wysoką pozycję należy nadać menedżerom ds. zarządzania relacjami z klientami;

- zarządzania procesami z jasno określoną odpowiedzialnością;

- pomiaru lojalności klientów i lojalności własnej wobec klienta oraz metod budowania lojalności, jak na przykład NPS;

- rozwinięcia procesu zarządzania interakcjami z klientami;

- ustanowienia zespołu ds. zarządzania relacjami z klientami i zastosowania specyficznej motywacji i schematów nagród dla menedżerów.

Należy wskazać na możliwość wykorzystania implikacji menedżerskich, zawartych $\mathrm{w}$ wynikach artykułu, także $\mathrm{w}$ zarządzaniu relacjami $\mathrm{w}$ innych kontekstach usług $\mathrm{z}$ intensywnym kontaktem, w których odbywają się długoterminowe relacje z klientami. Ograniczeniem wyników badania są przyjęte jakościowe metody badawcze oraz specyfika kontekstu usług produkcyjnych wraz z analizowanymi przypadkami współpracy usługodawców zlokalizowanych $\mathrm{w}$ Polsce z zachodnimi klientami oferującymi produkty z własną marką. Kolejnym etapem mogą być badania ilościowe na reprezentatywnej grupie przedsiębiorstw świadczących usługi produkcyjne w ramach węższego aspektu zarządzania relacjami B2B ze wskazaniem na budowanie lojalności relacyjnej. Badania jakościowe w innych kontekstach usług $\mathrm{z}$ intensywnym kontaktem mogłyby dostarczyć dodatkowych wniosków na temat znaczenia i istotności lojalności relacyjnej w zarządzaniu relacjami.

${ }^{40}$ D. Siemieniako, Model... 


\section{LITERATURA}

[1] Aksoy L., How do you measure what you can't define? The current state of loyalty measurement and management, ,Journal of Service Management”24/4 (2013).

[2] Barry J., Terry T.S., Empirical study of relationship value in industrial services, „Journal of Business \& Industrial Marketing" 23/4 (2008).

[3] Fournier S., Consumers and Their Brands: Developing Relationship Theory in Consumer Research, „Journal of Consumer Research” 24/4 (1998).

[4] Geiger I., Kleinaltenkamp M., Instruments of Business Relationship Management, [w:] Business Relationship Management and Marketing, red. M. Kleinaltenkamp, I. Geiger, W. Plinke, Springer, Berlin 2015.

[5] Gil-Saura I., Frasquet-Deltoro M., Cervera-Taulet A., The value of B2B relationships, „Industrial Management \& Data Systems" 109/5 (2009).

[6] Gilliland D.I., Bello D.C., Two sides to attitudinal commitment: The effect of calculative and loyalty commitment on enforcement mechanisms in distribution channels, „Journal of the Academy of Marketing Science" 30/1 (2002).

[7] Grönroos C., Marketing as promise management: regaining customer management for marketing, „Journal of Business \& Industrial Marketing” 24/5-6 (2009).

[8] Grönroos C., Search of New Logic for Marketing: Foundations of Contemporary Theory, John Wiley \& Sons, London 2007.

[9] Hetesi E., The Effects of Recession on B2B Loyalty, ,Journal of Marketing Development and Competitiveness" 8/2 (2014).

[10] Lindgreen A., Wynstra F., Value in business markets: what do we know?, ,Industrial Marketing Management” 34/7 (2005).

[11] Morgan R.M., Hunt S.D., The commitment-trust theory of relationship marketing, „Journal of Marketing" 58/3 (1994).

[12] Naumann E., Williams P., Khan M.S., Customer satisfaction and loyalty in B2B services: directions for future research, ,The Marketing Review” 9/4 (2009).

[13] Rust R.T., Lemon K.N., Zeithaml V.A., Return on marketing: using customer equity to focus marketing strategy, „Journal of Marketing” 68/1 (2004).

[14] Siemieniako D., Budowa zaufania klientów w warunkach niepewności na przykładzie kryzysu systemu finansowego, „Marketing i Rynek” 2009/7.

[15] Siemieniako D., Logika ustugowej dominacji $w$ marketingu - podstawowe pojęcia $i$ konsekwencje w zarządzaniu, „Marketing i Rynek” 2008/11.

[16] Siemieniako D., Lojalność klientów - historia czy rzeczywistość marketingu?, „Marketing $\mathrm{i}$ Rynek” 2010/5.

[17] Siemieniako D., Lojalność relacyjna a zobowiązanie $w$ złożonych związach ustugowych, „Marketing i Rynek” 2011/8.

[18] Siemieniako D., Model zarządzania lojalnościa relacyjna oparta na zobowiąaniu $w$ związkach ustugowych, „Marketing i Rynek” 2012/5.

[19] Siemieniako D., Rola empatii w budowaniu lojalności relacyjnej klientów, „Zeszyty Naukowe Uniwersytetu Szczecińskiego. Problemy Zarządzania, Finansów i Marketingu” 2010/15.

[20] Siemieniako D., Typy lojalności relacyjnej opartej na zobowiązaniu w złożonych związkach ustugowych, „Handel Wewnętrzny” 2012/1.

[21] Siemieniako D., Zarządzanie obietnica w logice ustugowej dominacji w dobie kryzysu zaufania (na przykładzie ustug finansowych), „Handel Wewnętrzny” maj 2009.

[22] Siemieniako D., Rundle-Thiele S., Urban W., Understanding loyalty from a customer's perspective, "Journal of Customer Behaviour" 9/3 (2010).

[23] Taylor T.A., Supply chain coordination under channel rebates with sales effort effects, "Management Science" 48/8 (2002).

[24] Vargo S.L., Lusch R.F., Evolving to a New Logic for Marketing, ,Journal of Marketing” 68/1 (2004). 
[25] Woodside A.G., Wilson E.J., Case study research methods for theory building, „Journal of Business \& Industrial Marketing" 18/6-7 (2003).

[26] Woodruff R.B., Customer value: The next source for competitive advantage, „Journal of the Academy of Marketing Science" 25/2 (1997).

\section{B2B RELATIONSHIP MANAGEMENT IN PRODUCTION SERVICES WITH DIRECTION OF RELATIONAL LOYALTY FORMATION}

$\mathrm{B} 2 \mathrm{~B}$ relationship management in production services is getting more and more important issue in the era of global, competitive markets, mutually connected. The important effect of B2B relationship management is customer loyalty, who undertake more often than disloyal customers and with bigger involvement the cooperation initiatives, which are necessary in realization of production services. In formation of relational loyalty in production services it was used the theoretical model proposed by Siemieniako [2012a]. The goal of the paper is identification and recognition of mechanisms of relational loyalty emerging, and actions which confirm loyalty existence, and the effects of loyalty in the process of B2B relationship management in the context of production services. It was used two research methods: individual interviews and case study research method. The research sample was the companies which offered the production services, mainly from the lines connected with production different kinds of devices, machines and components. The results of the research was presented based on the model of relationship management in production services with direction on relational loyalty formation, which consists of 7 elements. Mutual fit of processes, organizational culture and on personal level was showed as an important factor of relationship development and loyalty formation. The way of dealing from service provider side, with customer needs understanding, taking obligations and fulfilling promises market out the level of cooperation development with Western customers. It is condition of trust and taking obligations from customers side. The analysis of results allowed to identify the features of relational loyalty in production services and actions which confirm loyalty existence. The results showed also the effects of loyalty and the elements of management system in organization, which influence on effective relationship management with direction of relational loyalty formation.

Keywords: relational loyalty, relationship marketing, production services, case study, promise management

DOI: 10.7862/rz.2015.mmr.27

Przesłano do redakcji: sierpień 2015

Przyjęto do druku: sierpień 2015 